\title{
The Oakland Project
}

At a time when much is said but little is done about the university's relationship to urban problems, it is useful for those who are looking for ways of relating the university to the city to take a brief look at the Oakland Project of the University of California, which combines policy analysis, service to city officials and community groups, action in implementing proposals, training of graduate students, teaching new undergraduate courses, and scholarly studies of urban politics. The "university" is an abstraction, and as such it exists only for direct educational functions, not for the purpose of doing work within cities. Yet there are faculty members and students who are willing to devote large portions of their time and energy to investigating urban problems and to making small contributions toward resolving them. Our cities, however, do not need an invasion of unskilled students and professors. There is no point in hurtling into the urban crisis unless one has some special talent to contribute. After all, there are many people in city government-and even more on street corners-who are less inept than untrained academics. University people must offer the cities the talent and resources which they need and which they could not get otherwise.

Nearly four years ago I assembled a group of graduate students and faculty members at the University of California at Berkeley to become involved in a program of policy research and action 
in the neighboring city of Oakland. As members of the Oakland Project, we have tried to meet some of the city's most pressing analytical needs and also to make suggestions that can be implemented and, if successful, transferred to other urban areas.

Members of the project have made substantial time commitments (usually about two years) to working in a particular Oakland city agency. Normal working time has been two days a week, although special crisis situations in the city have sometimes necessitated much larger blocks of time. Since project members work with city officials and remain in the city to help implement the suggestions they have made, they avoid the "hitand-run" stigma that members of city agencies often attach to outsiders. By attempting first to deal with problems as city officials understand them, project members have developed the necessary confidence to be asked to undertake studies with broader implications.

The Oakland Project has become a point of communication for individuals and groups in the city of Oakland and throughout the University of California. Our focus has expanded from a concentration on city budgeting to a wide range of substantive policies and questions of political process; for example, revenue, police, personnel, federal aid, education, libraries, and the institutionalization of political change. We have provided assistance to governmental (mayor, city manager, chief of police, head of civil service, superintendent of schools) and nongovernmental (community group) actors. In order to transmit the knowledge we have gained, Oakland Project members have taught courses-open to both undergraduate and graduate students-dealing with urban problems and policies. Our scholarly objective is to improve policy analysis by providing new ways of understanding decisions and outcomes that affect cities. We have based numerous research essays on our experience in the city. We are hopeful that the books in this series will be another means of transmitting what we have learned to a wider audience. 